\title{
17 十、光灯少イリス夕調光にお计る諸间題
}

噪本健富土電工株式会社

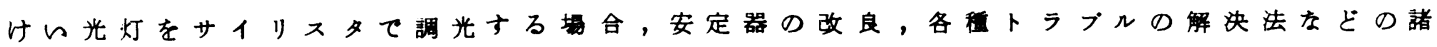
問題について述へる

\section{泟 $\pi$ 式点灯法}

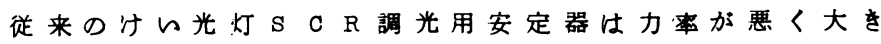
さ重量的大加九。1例を示すと㰠の通りてある。

力率 2 次無負荷電王, 入力電流電力. 重是

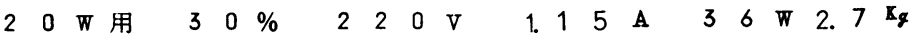

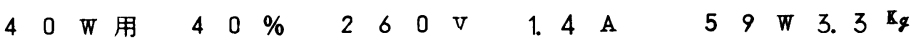

しかしサイリスタ調光器を通って出て来た出力波形は 第 1 図の上5反立ち上りの鋭的波形てるから，ての立 ち上りをコンテンサて微分してトランスてステップテッ ブしてての高い電匠をけい光灯に与えてゃると小型て力 率のよい安定器がてる。

第 2 因証常の予熱点灯用のチ 用のコイルをむき边んて作つたパストランス兼チョー クて，第 3 図の上5に数百 $\mathrm{V}$ のハルスが各サイクルの初

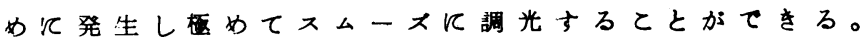

乙の安定器は力率 $65 \%$, 入力電流0. $375 \mathrm{~A}$, 重量 $400 \mathrm{~g} \tau$, 通常の安定器飞比へて力事 2 倍, 入力電流 3 分の 1 , 重量 7 分の 1 てある。

第 4 図岋 $40 \mathrm{~W}$ 用のハルス式安定器て, ヒ一タ一巻線 を1次コイ几側にまを，2忺飞流れる電流のみをサイリ スタに流す上5にすると, 小型軽量効率上いるのが得ら れる。乙の安定器は力率5 0 \%, サイリスタ電流 $0.435 \mathrm{~A}$

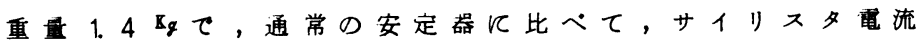

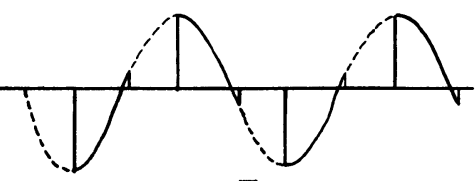

第 1 因
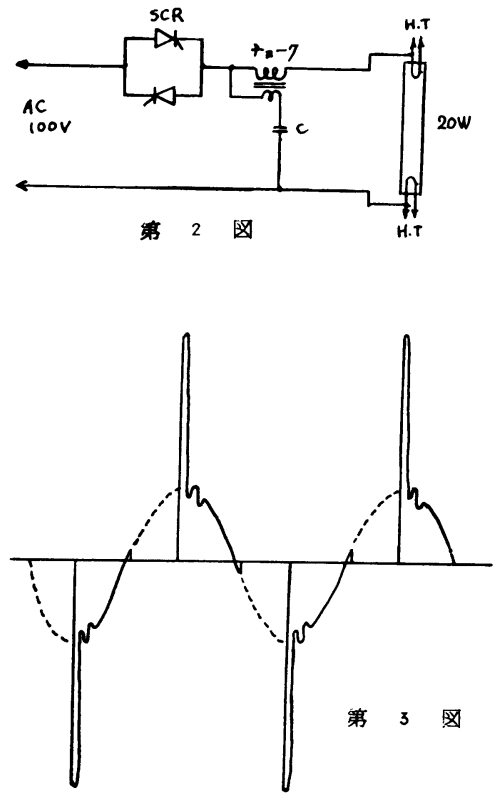
3 分の 1 重量 2. 5 分の1てすむ.コンテンサは $0.1 \mu \mathrm{F}$ 位てハルス正仕けい光灯の両端に1500 位発 生する。

近接導体にパスを加る方法

第 5 四の上5に近接導体にパスを加ける上 与にすると, 通常の予熱点灯用の汀的光灯安定 器を調光飞使用するととかでる。とのパス トランスは1:10位のものて,ヒータートランス

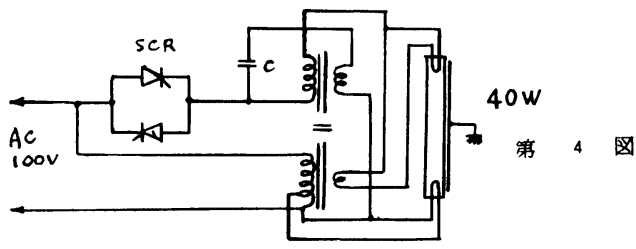
なとを流用するととがてをるし，たくさんのけい光灯を一ケ のバストランスてつ汁るてとるてを更に経済的てある。

トラプルの解决法

このよ5なし C 負荷のサイリスタは時にチラッキなどのト ラプルを起す，しCのQをサイリスタ㑡からみて下げるとと が必要てある。

参考文献実用新案公告 $41-17826$ 橋本健

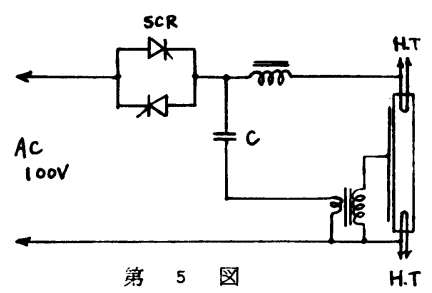

